\title{
Possible Common Origin of B Chromosomes in Neotropical Fish (Siluriformes, Auchenipteridae) Reinforced by Repetitive DNA Mapping
}

Roberto Laridondo Lui ${ }^{1}$

https://orcid.org/0000-0003-4310-4865

Josiane Baccarin Traldi ${ }^{2 *}$

https://orcid.org/0000-0003-3019-7441

Daniel Rodrigues Blanco ${ }^{3}$

https://orcid.org/0000-0003-1619-2417

Vladimir Pavan Margarido ${ }^{1}$

https://orcid.org/0000-0002-0823-6646

\author{
Sandra Mariotto 4 \\ https://orcid.org/0000-0003-4007-3100
}

\author{
Liano Centofante ${ }^{5}$ \\ https://orcid.org/0000-0003-0712-8149
}

Roberto Ferreira Artoni ${ }^{6}$

https://orcid.org/0000-0002-2528-9846

\author{
Orlando Moreira Filho ${ }^{7}$ \\ https://orcid.org/ 0000-0001-5137-0122
}

1Western Paraná State University, Center for Biological and Health Sciences, Collegiate of the Biological Sciences Course, Cascavel, Paraná, Brazil; ${ }^{2}$ Federal University of Amazonas, Institute of Biological Sciences, Department of Genetics, Manaus, Amazonas, Brazil; ${ }^{3}$ Federal Technological University of Paraná, Coordination of Biological Sciences, Santa Helena, Paraná, Brazil; ${ }^{4}$ Federal Institute of Education, Science and Technology of Mato Grosso, Bela Vista Campus, Cuiabá, Mato Grosso, Brazil; ${ }^{5}$ Federal University of Mato Grosso, Institute of Biosciences, Department of Biology and Zoology, Cuiabá, Mato Grosso, Brazil; ${ }^{6}$ Ponta Grossa State University, Department of Structural, Molecular and Genetic Biology, Ponta Grossa, Paraná, Brazil; ${ }^{7}$ Federal University of São Carlos, Center for Biological and Health Sciences, Department of Genetics and Evolution, São Carlos, São Paulo, Brazil.

Editor-in-Chief: Paulo Vitor Farago

Associate Editor: Camila Fediuk de Castro Guedes

Received: 2019.08.14; Accepted: 2021.02.23.

*Correspondence: jositraldi@hotmail.com; Tel.: +55-92-3305-2380 (J.B.T.).

\section{HIGHLIGHTS}

- B chromosomes of different species have a common origin.

- B chromosomes similarities suggest Parauchenipterus diagnosis is likely not valid.

Abstract: The aim of this paper was to present the second case of B chromosomes in Auchenipteridae (Trachelyopterus sp.), and to test the hypothesis that the B chromosomes of this species and Parauchenipterus galeatus might have a common origin, since these two species have phylogenetic proximity. Both species have 58 chromosomes in the A complement, heterochromatin preferentially located at terminal region of the most of chromosomes, simple Ag-NORs located at the short arm of a subtelocentric pair, which was confirmed by hybridization with 18S rDNA, two submetacentric pairs carrying 5S rDNA sites, and presence of B chromosomes. The B chromosomes of the two species are small, metacentric, and almost totally heterochromatic, with variation of number intra and interindividual. In addition, for the first time in fish, the telomeric sequence [TTAGGG] $]_{n}$ was dispersed along the $B$ chromosomes (both species). The [GATA $]_{n}$ microsatellite were scattered in all chromosomes of the A complement and absent in the B chromosomes, in both species. These aspects confirm the phylogenetic proximity between the genus Parauchenipterus and Trachelyopterus, and they suggest the hypothesis that 
the $\mathrm{B}$ chromosomes of the two species might have common origin, previous to the diversification of these genera.

Keywords: chromosome evolution; [TTAGGG]n; [GATA]n; Parauchenipterus; Trachelyopterus.

\section{INTRODUCTION}

B chromosomes occur in almost $10-15 \%$ of eukaryotic species, which makes them an important aspect in the understanding of genomic evolution [1]. According to Camacho [2], they are additional and dispensable, occur in some individuals of some populations, were probably originated from the A chromosomes, but follow on their own evolution. Therefore, B chromosomes are not essential elements for the growth, development and reproduction of the organisms. According to Jones \& Rees [3], the term B chromosome should be used only for the cases in which its frequency in the population is known, being an intrinsic characteristic of this population.

Many recent studies have shown that $B$ chromosomes carry genes that participate in various biological functions [4], and can also causes differential expression of genes located in A chromosomes [5]. In fish, various classes of repetitive DNAs, such as satellites, ribosomes and transposable elements, and simple copy genes have already been found $[4,6]$. Several examples can be presented: the As51 satellite DNA was found on B chromosomes of Astyanax scabripinnis [7]; the SATH1 repetitive DNA was verified on the B chromosomes of Prochilodus lineatus [8]; a retrotransposon was identified on B chromosomes of Alburnus alburnus [9]; genes encoding proteins were found on B chromosomes of cichlid species of Lake Victoria [6]; the genes IHHB and 45S rRNA were found in B chromosomes of Astatotilapia latifasciata [10].

For fish, 278 reports of B chromosomes are described, which include several families [11]. Approximately half of the Neotropical fish species that have B chromosomes are Characiformes $50,82 \%$ and $35 \%$ are Siluriformes of the total species with B chromosomes [12]. The latter order includes six families that have B chromosomes: Auchenipteridae, Callichthyidae, Heptapteridae, Pimelodidae, Trichomycteridae and Loricariidae [12,13]. Auchenipteridae consists of small to medium sized catfish, endemic to the Neotropical region, with 125 valid species [14]. This family has two subfamilies, Centromochlinae and Auchenipterinae [15,16]. Parauchenipterus and Trachelyopterus are taxonomically allocated in the latter one. According to Akama [17], these two genera should be sister-groups. Auchenipteridae has two species that present B chromosomes; they are presented in this paper: Parauchenipterus galeatus $[13,18]$ and Trachelyopterus sp. The other species of this subfamily which were chromosomally studied do not have B chromosomes [19-24].

This article aimed at presenting the second case of B chromosomes in Auchenipteridae (Trachelyopterus sp.), and testing the hypothesis that the B chromosomes of this species and Parauchenipterus galeatus might have a common origin, since these two species have phylogenetic proximity.

\section{MATERIAL AND METHODS}

We analyzed ten individuals (seven females and three males) of $P$. galeatus from a pond of the São Francisco right river bank, in Lagoa da Prata, Minas Gerais state, Brazil (GPS 1956'15.1"S; $45^{\circ} 32$ '13.8' W), and six individuals (three females and three males) of Trachelyopterus sp. from Arrombado pond, which is supplied by Bento Gomes River, a tributary of Cuiabá River, Poconé, Mato Grosso state, Brazil (GPS 16²5'40.9”S; 56 ${ }^{\circ} 25^{\prime} 07.4^{\prime \prime} \mathrm{W}$ ). All samples were carried out with the authorization of the Instituto Chico Mendes de Conservação da Biodiversidade (ICM-Bio; License No. 10538-1). Procedures were performed according to the Ethics Committee on Animal Experimentation and Practical Classes from Unioeste: 13/09 - CEEAAP/Unioeste. The specimens were deposited in the fish colletion of the Museu de Zoologia da Universidade de São Paulo (MZUSP 100985 and MZUSP 110806).

Cell suspensions with mitotic chromosomes were obtained from anterior kidney cells [25-27]. Chromosomes were stained with 5\% Giemsa solution. Chromosome morphologies were determined according to the arms ratio of Levan et al. [28]. Fundamental numbers (FN) were established considering metacentric $(\mathrm{m})$, submetacentric $(\mathrm{sm})$ and subtelocentric (st) chromosomes as carriers of two arms, and acrocentric chromosomes (a) as carriers of only one arm. The heterochromatin pattern was determined by the method of Sumner [29], with changes in the staining step [30]. Nucleolus organizer regions (NORs) were identified using silver nitrate impregnation [31], in chromosomes previously analyzed by Giemsa and C-banding (sequential analysis). 
Fluorescence in situ hybridizations (FISH) were performed according to Pinkel et al. [32]. The 5S rDNA and 18S rDNA probes were obtained according to Martins et al. [33] and Hatanaka \& Galetti Jr [34], respectively. They were labeled by nick translation, with biotin-16-dUTP (rDNA 5S) and digoxigenin-11dUTP (rDNA 18S) (Roche). The repetitive sequences [TTAGGG] $]_{\mathrm{n}}$ and $[\mathrm{GATA}]_{\mathrm{n}}$ were amplified and labeled by Polimerase Chain Reaction (PCR) [35], with dUTP-16-biotin (Roche). The hybridizations were performed under high stringency conditions - 77\% (200 ng of each probe, 50\% formamide, 10\% dextran sulfate, $2 \times \mathrm{SSC} \mathrm{pH} 7.0$, at $37^{\circ} \mathrm{C}$, incubation of 16 hours). After hybridization, the slides were washed in $15 \%$ formamide / $0.2 x S S C$ solution at $42{ }^{\circ} \mathrm{C}$ for 20 minutes. Detection and amplification of the probes signals were performed using avidin-FITC and anti-avidin / biotin (Sigma) or anti-digoxigenin / rhodaminelabeled. The chromosomes were counterstained with antifading / DAPI solution $(20 \mu \mathrm{L}$ of antifading +0.1 $\mu \mathrm{L}$ of DAPI - $0.2 \mathrm{mg} / \mathrm{ml}$ ) and analyzed in an Olympus BX50 epifluorescence microscope. DP2-BSW software (Olympus) was used to capture the images.

\section{RESULTS}

\section{Parauchenipterus galeatus}

Individuals of both sexes presented 58 chromosomes $(22 m+16 s m+12 s t+8 a, F N=108)$ (Figure 1a). Cells of seven animals (five females and two males) presented small and metacentric B chromosomes. Five females and one male had variation from zero to up two B chromosomes, and other male had variation from zero to up one $B$ chromosome (Table 1). Among the specimens with $B$ chromosomes, the frequency of cells bearing such chromosomes ranged from $55 \%$ to $86 \%$ (Table 1). The heterochromatin was dispersed in the terminal position of some A chromosomes (Figure 1b). B chromosomes were completely heterochromatic (Figure 1a, highlighted).

Single NOR was located in terminal position of the short arm of pair 23 (Figure 1a, highlighted). Hybridization with 18S rDNA confirmed the result of silver nitrate impregnation (Figure 2a). 5S rDNA sites were evidenced in the interstitial position of the short arm of the pair 16, and in the long arm of the pair 17 (Figure 2a). Hybridization with telomeric probe [TTAGGG] $]_{n}$ showed labeling in the terminal region of all $A$ chromosomes complement (Figure 2c). Such sequence showed itself amplified and dispersed along $B$ chromosomes (Figure 2c, arrows). FISH with $[\text { GATA }]_{n}$ probes located this sequence in terminal, subterminal and interstitial regions of the most of $A$ chromosomes complement, however, no signal was detected on B chromosomes (Figure 2e).

\section{Trachelyopterus sp.}

Individuals of both sexes presented 58 chromosomes $(22 m+20 s m+8 s t+8 a, F N=108)$ (Figure 1c). Cells of two animals (two females) presented small and metacentric B chromosomes. One female had variation from zero to up three B chromosomes, and the other one from zero to up two B chromosomes (Table 1). Among the specimens with $B$ chromosomes, the frequency of cells bearing such chromosomes ranged from $50 \%$ to $68 \%$ (Table 1). The heterochromatin was dispersed in the terminal position of the most $A$ chromosomes complement (Figure 1d). B chromosomes were completely heterochromatic (Figure 1c, highlighted).

Single NOR was located in terminal position of the short arm of pair 22, coinciding with the secondary constriction (Figure 1c, highlighted). Hybridization with 18S rDNA confirmed the result of silver nitrate impregnation (Figure 2b). 5S rDNA sites were evidenced in the interstitial position of the short arm of the pair 16, and in the long arm of the pair 18 (Figure 2b). Hybridization with telomeric probe [TTAGGG]n showed labeling in the terminal region of all A chromosomes complement (Figure 2d). Such sequence was amplified and dispersed along B chromosomes (Figure 2d, arrows). FISH with [GATA] n probes located this sequence in terminal and subterminal regions of the most of $A$ chromosomes complement, however, no signal was detected on B chromosomes (Figure 2f). 
Table 1. Frequency of cells bearing B chromosomes in Parauchenipterus galeatus and Trachelyopterus sp.

\begin{tabular}{|c|c|c|c|c|c|c|c|c|}
\hline \multirow[t]{2}{*}{ Species } & \multirow[t]{2}{*}{ Specimen } & \multirow[t]{2}{*}{ Sex } & \multicolumn{4}{|c|}{$\begin{array}{l}\text { Number of methapases } \\
\text { analyzed per specimen }\end{array}$} & \multirow{2}{*}{$\begin{array}{l}\text { Cells with } \\
\text { B (\%) }\end{array}$} & \multirow[t]{2}{*}{ Total } \\
\hline & & & OB & 1B & 2B & 3B & & \\
\hline \multirow{6}{*}{$\begin{array}{l}\text { Parauchenipterus } \\
\text { galeatus }\end{array}$} & 1 & $q$ & 12 & 10 & 13 & - & 65,7 & 35 \\
\hline & 2 & 오 & 33 & - & - & - & - & 33 \\
\hline & 3 & 오 & 08 & 05 & 05 & - & 55,5 & 18 \\
\hline & 4 & $\hat{\sigma}$ & 28 & 30 & 15 & - & 61,6 & 73 \\
\hline & 5 & q & 02 & 03 & 01 & - & 66,7 & 06 \\
\hline & 6 & o & 09 & 10 & 02 & - & 57,1 & 21 \\
\hline \multirow{5}{*}{$\begin{array}{c}\text { São Francisco River } \\
\text { basin }\end{array}$} & 7 & $\hat{0}$ & 04 & 05 & - & - & 55,5 & 09 \\
\hline & 8 & $q$ & 08 & 19 & 31 & - & 86,2 & 58 \\
\hline & 9 & $\hat{0}$ & 11 & - & - & - & - & 11 \\
\hline & 10 & o & 28 & - & - & - & - & 28 \\
\hline & Total & & 143 & 82 & 67 & - & $68 \% 1$ & 292 \\
\hline \multirow{3}{*}{ Trachelyopterus sp. } & 1 & q & 02 & - & - & - & - & 02 \\
\hline & 2 & 우 & 17 & 30 & 06 & - & 68 & 53 \\
\hline & 3 & $\hat{0}$ & 09 & - & - & - & - & 09 \\
\hline \multirow{4}{*}{$\begin{array}{l}\text { Paraguai River } \\
\text { basin }\end{array}$} & 4 & $\widehat{0}$ & 11 & - & - & - & - & 11 \\
\hline & 5 & o & 15 & 07 & 03 & 05 & 50 & 30 \\
\hline & 6 & $\hat{\sigma}$ & 11 & - & - & - & - & 11 \\
\hline & Total & & 65 & 37 & 09 & 05 & $61 \%^{1}$ & 116 \\
\hline
\end{tabular}

1 The total frequency of cells is only considering specimens that showed B chromosomes.

a

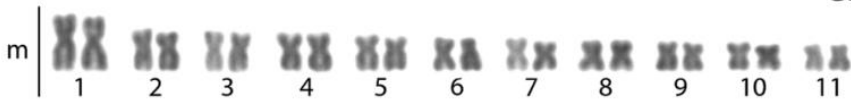

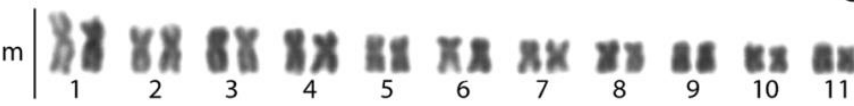

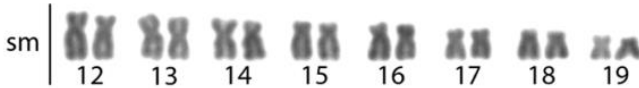

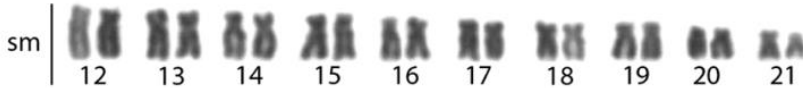

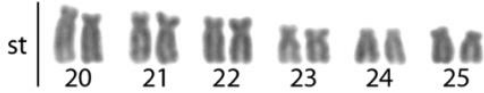

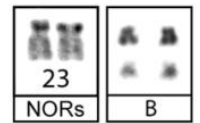

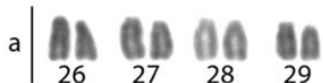

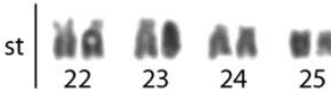

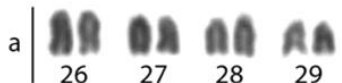

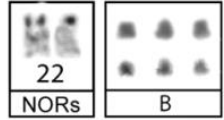

b

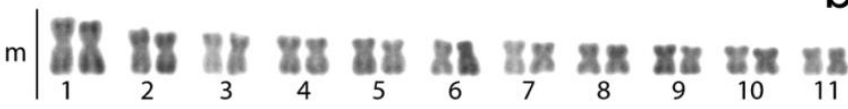

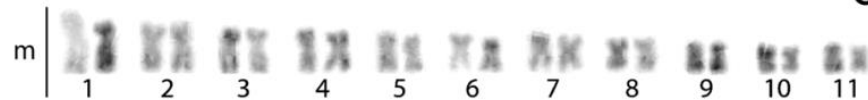

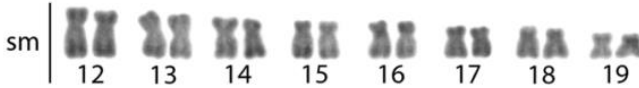

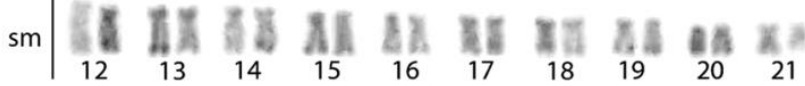

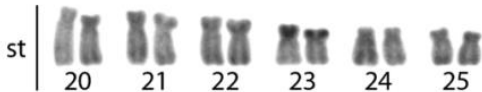

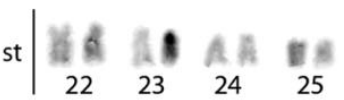

a|

a $\mid \begin{array}{lllll}\text { A A A } & \text { A } & \text { A } & \text { A A A } \\ 26 & 27 & 28 & 29\end{array}$

10 而而

Figure 1. Karyotype of $P$. galetatus with (a) conventional Giemsa staining and (b) C-banding. Karyotype of Trachelyopterus sp. with (c) conventional Giemsa staining and (d) C-banding. Chromosomes bearing NORs and B chromosomes are highlighted in boxes. 


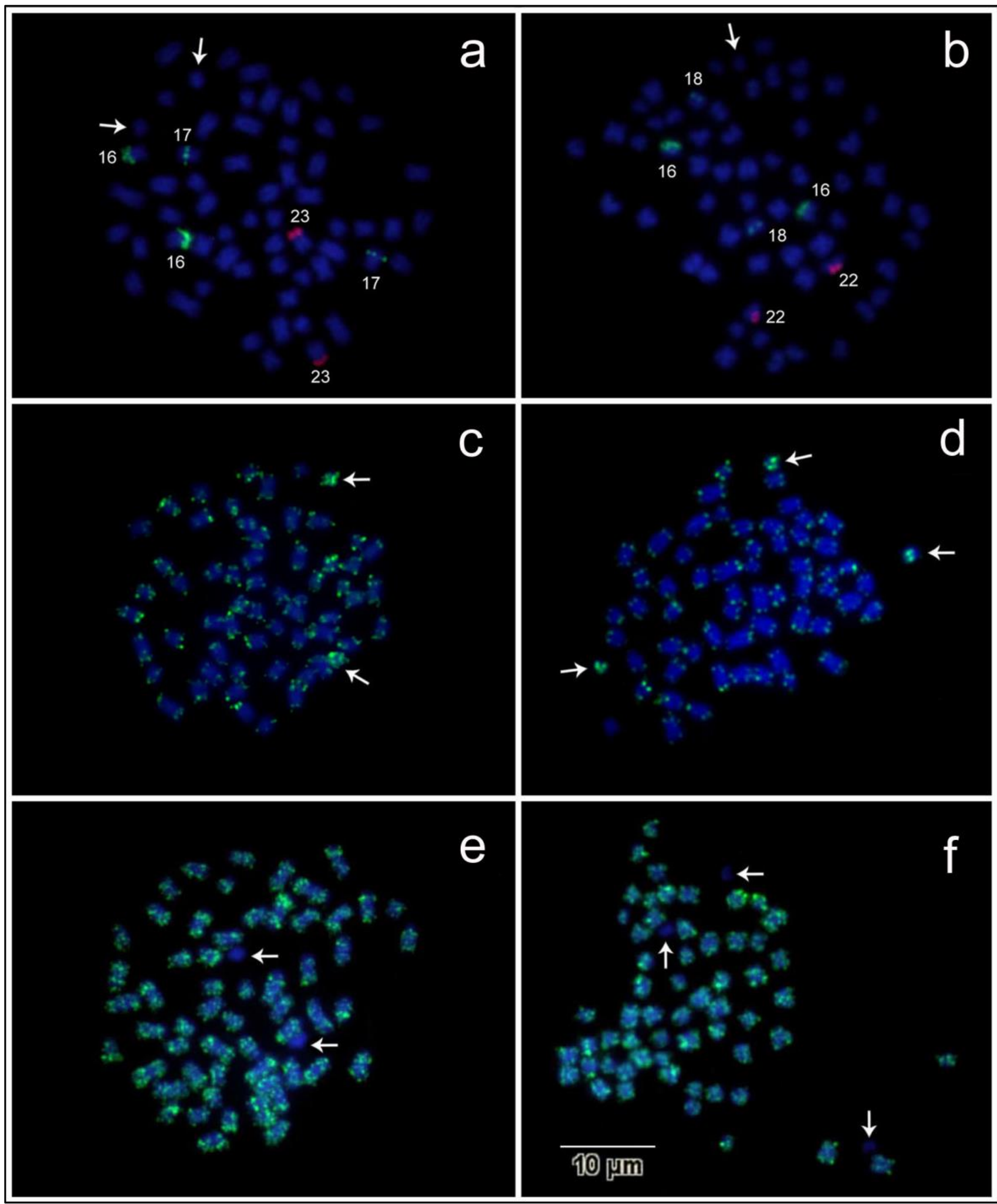

Figure 2. Metaphases of $P$. galeatus hybridized with (a) rDNA 18S (red) and rDNA 5S (green), (c) telomeric sequence [TTAGGG]n, and (e) [GATA]n repeats. Metaphases of Trachelyopterus sp. hybridized with (b) rDNA 18S (red) and rDNA 5S (green), (d) telomeric sequence [TTAGGG]n, and (f) [GATA]n repeats. The arrows indicate the $B$ chromosomes on metaphases. 


\section{DISCUSSION}

Parauchenipterus and Trachelyopterus are considered as sister group, which is reinforced by the taxonomic problem of the group [17]. The characteristics analyzed for $P$. galeatus e Trachelyopetrus sp. in this paper reinforce this proximity, since they evidenced high chromosome similarities: maintenance of the diploid number $(2 n=58)$, heterochromatin dispersed in the terminal region of the most of $A$ chromosomes, single terminal NORs located in the short arm of a subtelocentric pair (confirmed by FISH with 18S rDNA), two pairs bearing 5S rDNA sites, and similarities between B chromosomes. The few number of Auchenipteridae studies [13,18-24,36] suggest that this conserved chromosome macrostructure is recurrent in the family, and most of the differences found are usually due to non-robertsonian rearrangements [18]. This situation of little variation is not unique to these species, since many groups of Neotropical fish exhibit relative karyotype conservatism [37-39].

The C-banding pattern of the both species analyzed here were similar, with small blocks located in the terminal region of the most chromosomes. Similar pattern of C-banding occurs in other Auchenipteridae species, like Auchenipterus osteomystax cit. Auchenipterus nuchalis [20], Glanidium ribeiroi [20,21,24], $P$. galeatus [13,18,20], Tatia jaracatia, Tatia neivai [22] and Tympanopleura atronasus cit. Ageneiosus atronasus [19], suggesting that this is a common feature of the family. However, in Ageneiosus inermis cit. Ageneiosus brevifilis [19] and $A$. inermis [23], prominent blocks were detected [23]. The $\mathrm{B}$ chromosomes of the two species analyzed were completely heterochromatic, as it was observed in the most of the Neotropical fish species that present this type of chromosome [40,41].

In all Auchenipteridae species analyzed by the cytogenetics, the NORs are simple, but their location may be interstitial or terminal, according to species. In $A$. inermis [19], $P$. galeatus $[13,18,20,36], T$. jaracatia, T. neivai [22], $A$. inermis [23], and Trachelyopterus sp. (this paper) NORs were terminal; in $A$. osteomystax [20], G. ribeiroi [20,21,24], and T. atronasus [19] NORs were interstitial. In all species that have 18S rDNA mapping data, it was confirmed the result obtained by silver nitrate impregnation $(13,18,21$ 24). These similar results for the two species analyzed in the present paper reinforce the phylogenetic proximity of these genera. A small difference in relation to this marker can be observed: in $P$. galeatus the NORs are coincident with a region of heterochromatin, whereas in Trachelyopterus sp. are C-banding negative.

The distribution pattern of $5 S$ rDNA in Auchenipteridae is more variable than $18 S$ rDNA. Populations of $P$. galeatus have two pairs bearing this sequence [13,18, present paper]; in $T$. jacaratia four pairs were identified [22]; for T. neivai sites were observed in three pairs [22] in A. inermis [23]; in G. ribeiroi [24] only one pair was identified, and in Trachelyopterus sp. two pairs were found (present study). Although they are allocated in different chromosome pairs, the sites evidenced in P. galeatus and Trachelyopterus sp. can be considered as homeologous, which reinforces the proximity of these species.

In both species analyzed in the present paper, the telomeric sequence [TTAGGG] $n$ was only found in the terminal portions of all autosomal chromosomes, like it was verified in G. ribeiroi [24], however, B chromosomes exhibited accumulation of this sequence. Most studies with B chromosomes indicate the presence this sequence only in the terminal region these chromosomes [27,42]. Cases of $B$ chromosomes bearing interstitial sites of telomeric sequence have also been described, as for example in Nyctereutes procyonoides [43] and Nectomys squamipes [44]. This unusual dispersion of telomeric sequence on B chromosomes of $P$. galeatus and Trachelyopterus sp. indicates a strong similarity between $\mathrm{B}$ chromosomes composition of these species. After the formation of a $B$ chromosome, it is common for them to undergo degeneration through repetitive DNA accumulation [1], which in these species appears to have occurred with telomeric sequences.

The $[\mathrm{GATA}]_{n}$ repeats, which were discovered by Epplen et al. [45], appears to be associated to determination and evolution of sex chromosomes in snake groups [46], and to initial stages in the origin of sex chromosomes in poecilids [47], and they are possibly related to gene regulation [48]. In the present study, [GATA $]_{n}$ repeats were located at the terminal region of all A chromosomes, as observed in $A$. inermis [20] and G. ribeiroi [24], in this same family of fishes. However, B chromosomes showed no hybridization signal for this microsatellite. Despite the absence of hybridization signals of the [GATA]n repeats on these chromosomes, it cannot be ruled out this sequence may be present in a low number of copies, which would not be detectable by FISH. This result also reinforces the similarity between the B chromosomes of the analyzed species.

The data obtained in the present study show that $B$ chromosomes organization in the two species is little different from A chromosomes organization, besides indicating a great similarity in the B chromosomes composition of these two species. It is important to note that the population of $P$. galeatus from Lagoa da 
Prata [13, present work] is the only one that presented B chromosomes, which represents $20 \%$ of all analyzed populations of this species, considering only published data [13, 18, 20, 36]. These similarities suggest common origin for these chromosomes of $P$. galeatus and Trachelyopterus sp. In this scenario, two hypotheses may explain the appearance of these chromosomes: (i) these chromosomes may have originated from a chromosome breakdown process which involved the terminal region an A chromosome, with concomitant loss of [GATA $]_{n}$ repeats or ii) after the origin of these $B$ chromosomes, the telomere sequence $[T T A G G G]_{n}$ would be amplified, with concomitant loss of [GATA $]_{n}$ repeats. The second hypothesis seems to be more plausible, due to the fact that these $B$ chromosomes have definite metacentric morphology. The changes observed in B chromosomes in relation to A chromosomes may have occurred due to the high dynamism that is normally attributed to these chromosomes.

For a long time it was believed that the B chromosomes carry no function. However, many recent studies have shown that there are several types of important genes located in B chromosomes, like genes involved in developmental processes [6,10], chromosome segregation and telomeres formation [49], regulate cell proliferation [50], gene silencing [51] and cell cycling and cell death [52]. Other studies also show that B chromosomes can interfere with transcription of genes located in complement A chromosomes, as observed in Eyprepocnemis plorans [5]. The present work identified a large amount of telomeric sequence in the B chromosomes of both species analyzed, however more studies are needed to identify whether such chromosomes have active genes and have an effective participation in cell functions.

According to Camacho et al. [53], the highest number of B chromosomes in a population is the result of interactions between the accumulation system (increased frequency) and harmful effects that these chromosomes can generate to the carriers. In almost $40 \%$ of cases in Neotropical fish, only one B chromosome was found per individual [12]. The highest number of $B$ chromosomes in $P$. galeatus and Trachelyopterus sp. were different, being two and three, respectively. However the two populations showed frequencies of cells with B chromosomes in the carrier specimens greater than $50 \%$, varying in $P$. galeatus from 55\% to $86 \%$, and in Trachelyopterus sp. from $50 \%$ to $68 \%$. The inter and intraindividual variation of $\mathrm{B}$ chromosome frequency in both species reflects mitotic instability, probably due to non-Mendelian behavior during cell division, as originally proposed by Jones \& Rees [3].

According to Camacho [1], B chromosomes may have long life and the best evidence of this would be the presence of similar B chromosomes in closely related species, like was shown in the species of this paper. The data presented suggest that these B chromosomes have a common origin and should have remained after the speciation processes of the clade (Parauchenipterus + Trachelyopterus), or the possible Parauchenipterus validation must be rethought like suggested by some authors. Moreover, it is probable that other populations of this fish group may also have B chromosomes. A similar case of common ancestral origin is documented in rye, between Secale cereale and $S$. segetale, in which the B chromosomes of the two species show meiotic pairing in interspecific hybrids [54]. According to Camacho [1], this case of rye species would require more studies to confirm the ancestry, specifically in relation to the DNA content of these B chromosomes. In the present study, these molecular information about $B$ chromosomes are provided by repetitive elements [TTAGGG $]_{n}$ and $[G A T A]_{n}$.

In general, the two species presented in this paper have a very similar chromosome constitution in relation to $A$ and $B$ chromosomes. These aspects reinforce the hypothesis that $B$ chromosomes present in both species might have common origin, previous to diversification this group.

Funding: This work was financed by Fundação de Amparo à Pesquisa do Estado de São Paulo (FAPESP), Conselho Nacional de Desenvolvimento Científico e Tecnológico (CNPq) and Coordenação de Aperfeiçoamento de Pessoal de Nível Superior (CAPES) and Fundação Araucária de Apoio ao Desenvolvimento Científico e Tecnológico do Paraná (FA).

Acknowledgments: The authors are grateful to Dr. Heraldo Antonio Britski for specimens identification, to Luis Henrique da Silva and Pedro Luis Gallo for helping with the sampling and technical support, and to Instituto Chico Mendes de Conservação da Biodiversidade (ICMBio) for the authorization to collect the material.

Conflicts of Interest: The authors declare no conflict of interest. The funders had no role in the design of the study; in the collection, analyses, or interpretation of data; in the writing of the manuscript, or in the decision to publish the results. 


\section{REFERENCES}

1. Camacho JPM. B Chromosomes. In: Gregory TR, editor. The Evolution of the Genome. San Diego: Elsevier Academic Press; 2005. 223-86.

2. Camacho JPM. Polymorphisms and geographic distribution. Proc First B Chromosome Conference; Madrid; 1993.2-4.

3. Jones RN, Rees H (1982) B chromosomes. Academic Press, London.

4. Ahmad SF, Martins C. The Modern View of B Chromosomes Under the Impact of High Scale Omics Analyses. Cells. 2019;8:156.

5. Navarro-Domínguez B, Martín-Peciña M, Ruiz-Ruano FJ, Cabrero J, Corral JM, López-León MD, Sharbel TF, Camacho JPM. Gene expression changes elicited by a parasitic B chromosome in the grasshopper Eyprepocnemis plorans are consistent with its phenotypic effects. Chromosoma. 2019;128(1):53-67.

6. Yoshida K, Terai Y, Mizoiri S, Aibara M, Nishihara H, Watanabe M, et al. B Chromosomes Have a Functional Effect on Female Sex Determination in Lake Victoria Cichlid Fishes. PLoS Genet. 2011;7(8):e1002203.

7. Mestriner CA, Galetti Jr PM, Valentini SR, Ruiz IRG, Abel LDS, Moreira-Filho O, et al. Structural and functional evidence that a B chromosome in the characid Astyanax scabripinnis is an isochromosome. Heredity. 2000;85:19.

8. Jesus CM, Moreira-Filho O. Chromosomal location of $5 \mathrm{~S}$ and $18 \mathrm{~S}$ rRNA genes in Prochilodus lineatus (Characiformes, Prochilodontidae). Caryologia. 2003;56:281-7.

9. Ziegler CG, Lamatsch DK, Steinlein C, Engel W, Schartl M, Schmid M. The giant B chromosome of the cyprinid fish Alburnus alburnus harbours a retrotrans-poson-derived repetitive DNA sequence. Chromosome Res. 2003;11:23-5.

10. Jehangir M, Ahmad SF, Cardoso AL, Ramos E, Valente GT, Martins, C. De novo genome assembly of the cichlid fish Astatotilapia latifasciata reveals a higher level of genomic polymorphism and genes related to $B$ chromosomes. Chromosoma. 2019;128(2):81-96.

11. D'Ambrosio U, Alonso-Lifante MP, Barros K, Kovarik A, Xaxar GM, Garcia S. B-chrom: a database on Bchromosomes of plants, animals and fungi. New Phytol. 2017;216(3):635-42.

12. Carvalho RA, Martins-Santos IC, Dias AL. B chromosomes: an update about their occurrence in freshwater Neotropical fishes (Teleostei). J. Fish Biol.2008;72:1907-32.

13. Lui RL, Blanco DR, Margarido VP, Moreira-Filho O. First description of B chromosomes in the family Auchenipteridae, Parauchenipterus galeatus (Siluriformes) of the São Francisco River basin (MG, Brazil). Micron. 2009;40:552-9.

14. Fricke R, Eschmeyer WN, Fong, JD. Species By family/Subfamily. San Francisco: California Academy of Sciences; updated in 2020 March 02; accessed in 2020 March 06. Available from: http://researcharchive.calacademy.org/research/ichthyology/catalog/SpeciesByFamily.asp. Accessed 06 March 2020.

15. Pinna MCC. Phylogenetics relationships of Neotropical Siluriformes: historical overview and synthesis of hypothesis. In: Malabarba LR, Reis RE, Vari RP, Lucena ZMS, Lucena CAS, editors. Phylogeny and classification of Neotropical Fishes. Porto Alegre: Edipucrs; 1998.279-330.

16. Ferraris Jr CJ. Family Auchenipteridae. In: Reis RE, Kullander SO, Ferraris Jr CJ, editors. Check List of Freshwater Fishes of South and Central America. Porto Alegre: Edipucrs; 2003.470-82.

17. Akama A. Sistemática dos gêneros Parauchenipterus Bleeker, 1862 e Trachelyopterus Valenciennes, 1840 (Siluriformes, Auchenipteridae) [thesis]. São Paulo: Universidade de São Paulo; 2004.

18. Lui RL, Blanco DR, Margarido VP, Moreira-Filho O. Chromosome characterization and biogeographic relations among three populations of the driftwood catfish Parauchenipterus galaetus (Linnaeus, 1766) (Siluriformes: Auchenipteridae) in Brazil. Biol J Linnean Soc. 2010;99:648-56.

19. Fenocchio AS, Bertollo LAC. Karyotype, C-bands and NORs of the neotropical siluriform fish Ageneiosus brevifilis and Ageneiosus atronases (Ageneiosidae). Cytobios. 1992;72:19-22.

20. Ravedutti CG, Júlio Jr HF. Cytogenetic Analysis of Three Species of the Neotropical Family Auchenipteridae (Pisces, Siluriformes) from the Paraná River Basin, Brazil. Cytologia. 2001;66:65-70.

21. Fenocchio AS, Dias AL, Margarido VP, Swarça AC. Molecular cytogenetic characterization of Glanidium ribeiroi (Siluriformes) endemic to the Iguaçu river, Brazil. Chromosome Sci. 2008;11:61-6.

22. Lui RL, Blanco DR, Margarido VP, Troy W, Moreira-Filho O. Comparative chromosomal analysis and evolutionary considerations concerning two species of genus Tatia (Siluriformes, Auchenipteridae). Comp Cytogenet. 2013;7:63-71. 
23. Lui RL, Blanco DR, Martinez JF, Margarido VP, Venere PC, Moreira-Filho O. The role of chromosomal fusion in the karyotypic evolution of the genus Ageneiosus (Siluriformes, Auchenipteridae). Neotrop Ichthyol. 2013;11:32734.

24. Lui RL, Blanco DR, Traldi JB, Margarido VP, Moreira-Filho O . Karyotypic variation of Glanidium ribeiroi Haseman, 1911 (Siluriformes, Auchenipteridae) along the Iguazu river basin. Braz J Biol. 2015;75,215-21.

25. Bertollo LAC, Takahashi CS, Moreira-Filho O. Cytotaxonomic consideration on Hoplias lacerdae (Pisces, Erythrinidae). Braz. J. Genet. 1978;1:103-20.

26. Foresti $F$, Oliveira $C$, Almeida-Toledo LF. A method for chromosome preparations from large fish specimens using in vitro short-term treatment with colchicines. Experientia. 1993;49:810-3.

27. Blanco DR, Bertollo LAC, Lui RL, Vicari MR, Margarido VP, Artoni RF, et al. A new technique for obtaining mitotic chromosome spreads from fishes in the field. J Fish Biol. 2012;81:351-7.

28. Levan A, Fredga K, Sandberg AA. Nomenclature for centromeric position on chromosomes. Hereditas. 1964; 52 : 201-20.

29. Sumner AT. A simple technique for demonstrating centromeric heterocromatin. Exp. Cell Res. 1972;75:304-6.

30. Lui RL, Blanco DR, Moreira-Filho O, Margarido VP. Propidium iodide for making heterochromatin more evident in the C-banding technique. Biotech Histochem. 2012;87(7):433-8.

31. Howell WM, Black DA. Controlled silver staining of Nucleolus Organizer Regions with protective colloidal developer: a one-step method. Experientia. 1980;36:1014-5.

32. Pinkel D, Straume T, Gray JW. Cytogenetic analysis using quantitative, high-sensitivity, fluorescence hybridization. Proc Natl Acad Sci USA. 1986;83:2934-8.

33. Martins C, Wasko AP, Oliveira C, Wright JM (2000) Nucleotide sequence of 5 S rDNA and localization of the ribosomal RNA genes to metaphase chromosomes of the Tilapiine cichlid fish, Oreochromis niloticus. Chromosome Res. 2000;133:39-46.

34. Hatanaka T, Galetti Jr PM. Mapping of the $18 \mathrm{~S}$ and $5 \mathrm{~S}$ ribosomal RNA genes in the fish Prochilodus argenteus Agassiz, 1829 (Characiformes, Prochilodontidae). Genetica. 2004;122:239-44.

35. Ijdo JW, Wells RA, Baldini A, Reeders ST. Improved telomere detection using a telomere repeat probe (TTAGGG)n generated by PCR. Nucleic Acids Res. 1991;19:4780.

36. Araujo, WC, Molina, WC. Citótipo exclusivo para Parauchenipterus galeatus (Siluriformes, Auchenipteridae) na Bacia do Atlântico NE Oriental do Brasil: Indicações de um complexo de espécies. 2010. Biota Amazonia. 2013;33-9.

37. Martins C, Galetti Jr PM. Karyotype similarity between two sympatric Schizodon fish species (Anostomidae, Characiformes) from the Paraguay River basin. Gen Mol Biol. 1998;21:355-60.

38. Martinez JF, Lui RL, Blanco DR, Traldi JB,Silva LF, Venere PC, et al. Comparative cytogenetics of three populations from the Rhamdia quelen species complex (Siluriformes, Heptapteridae) in two Brazilian hydrographic basins. Caryologia. 2011;64:121-8.

39. Traldi JB, Vicari MR, Martinez JF, Blanco DR, Lui RL, Moreira-Filho O. Chromosome Analyses of and (Characiformes, Parodontidae): An Extensive Chromosomal Polymorphism of 45S and 5S Ribosomal DNAs. Zebrafish. 2016;13:19-25.

40. Venere PC, Miyazawa CS, Galetti Jr PM. New Cases of Supernumerary Chromosomes in Characiform Fishes. Genet. Mol. Biol. 1999;22:345-9.

41. Penitente M, Foresti F, Porto-Foresti F. B chromosomes in the species Prochilodus argenteus (Characiformes, Prochilodontidae): morphological identity and dispersion. Comp Cytogenet. 2015;9(1):79-87.

42. Marques A, Klemme S, Guerra M, Houben A. Cytomolecular characterization of de novo formed rye B chromosome variants, Mol Cytogenet. 2012;5:34.

43. Wurster-Hill DH, Ward OG, Davis BH, Park JP, Moyzis RK, Meyne J. Fragile sites, telomeric DNA sequences, B chromosomes, and DNA cotent in raccoon dogs, Nyctereutes procyonoides, with comparative notes on foxes, coyote, wolf, and raccoon. Cytogenet. Cell. Genet. 1988;49:278-81.

44. Ventura K, O'Brien PCM, do Nascimento Moreira C, Yonenaga-Yasuda Y, Ferguson-Smith MA On the origin and evolution of the extant system of B chromosomes in Oryzomyini radiation (Rodentia, Sigmodontinae). PLoS ONE 2015;10:e0136663.

45. Epplen JT, McCarrey JR, Sutou S, Ohno S. Base sequence of a cloned snake W-chromosome DNA fragment and identification of a male-specific putative mRNA in the mouse. Proc Natl Acad Sci USA. 1982; 79: 3798-3802.

46. Jones KW, Singh L. Snakes and the evolution of sex chromosomes. Trends Genet. 1985;1:55-61.

47. Nanda I, Schartl M, Feichtinger W, Epplen JT, Schmid M. Early stages of sex chromosome differentiation in fish as analysed by simple repetitive DNA sequences. Chromosoma. 1992;101:301-10. 
48. Subramanian S, Mishra RK, Singh L. Genome-wide analysis of $B \mathrm{~km}$ sequences (GATA repeats): predominant association with sex chromosomes and potential role in higher order chromatin organization and function. Bioinformatics. 2003;19:681-5.

49. Valente GT, Conte MA, Fantinatti BEA, Cabral-De-Mello DC Carvalho, R.F.; Vicari, M.R.; Kocher, T.D.;Martins, C. Origin and evolution of $B$ chromosomes in the cichlid fish Astatotilapia latifasciata based on integrated genomic analyses. Mol Biol Evol. 2014;31:2061-72.

50. Makunin Al, Rajičić M, Karamysheva TV, Romanenko SA, Druzhkova AS, Blagojević J, Vujošević M, Rubtsov NB, Graphodatsky AS, Trifonov, V.A. Low-pass single-chromosome sequencing of human small supernumerary marker chromosomes (sSMCs) and Apodemus B chromosomes. Chromosoma. 2018;127:301-11.

51. Ma W, Gabriel TS, Martis MM, Gursinsky T, Schubert V, Vrána J, Doležel J, Grundlach H, Altschmied L, Scholz $\mathrm{U}$, et al. Rye $\mathrm{B}$ chromosomes encode a functional Argonaute-like protein with in vitro slicer activities similar to its A chromosome paralog. New Phytol. 2017;213:916-28.

52. Navarro-Domínguez B, Ruiz-Ruano FJ, Cabrero J, Corral JM, López-León M.D, Sharbel TF, Camacho JPM. Protein-coding genes in B chromosomes of the grasshopper Eyprepocnemis plorans. Sci Rep. 2017;7:45200.

53. Camacho JPM, Sharbel TF, Beukeboom LW. B-chromosome evolution. Philos Trans R Soc London B Biol Sci. 2000;55:163-78

54. Niwa K, Sakamoto S. Origin of B-chromosomes in cultivated rye. Genome. 1995;38:307-12.

CC (7) (S) 2021 by the authors. Submitted for possible open access publication under the terms and conditions of the Creative Commons Attribution (CC BY NC) license (https://creativecommons.org/licenses/by-nc/4.0/). 